\title{
Psikologi Islam Kontemporer
}

\author{
Sari Narulita \\ Universitas Negeri Jakarta \\ neesaa_98@yahoo.com
}

\begin{abstract}
This study stems from Dr. Zakiah Drajat who began to introduce the psychology of religious views. However, it was not until 1994 that through the national symposium, Islamic psychology enthusiasts were finally collected and came to an agreement to name the new knowledge in the name of Islamic psychology, after many names were proposed, among them the Psychology of Qur'ani, Psychology of Tasawwuf and so on. Islam is a concept that is outside of its adherents; but as a belief, Islam became part of its adherents. To deepen the psychology of the Muslims, it takes a separate study that has not been touched by the study of western psychology. This study is the focus of the study of Islamic psychology.
\end{abstract}

Keywords: Islamic Psychology, Psychiatry, Western Psychology

\begin{abstract}
Abstrak
Kajian ini bermula dari usaha Dr. Zakiah Drajat yang mulai mengenalkan psikologi dari tinjauan agama. Namun baru pada tahun 1994, melalui simposium nasional, para peminat psikologi Islam akhirnya dikumpulkan dan muncullah kesepakatan untuk menamakan pengetahuan baru tersebut dengan nama psikologi Islam, setelah sebelumnya, banyak nama diusulkan, di antaranya adalah Psikologi Qur'ani, Psikologi Tasawwuf dan lain sebagainya. Islam adalah konsep yang berada di luar diri pemeluknya; namun sebagai keyakinan, Islam menjadi bagian dari pemeluknya. Untuk mendalami kejiwaan kaum muslim, dibutuhkan kajian tersendiri yang selama ini tidak tersentuh oleh kajian psikologi barat. Kajian inilah yang menjadi fokus kajian psikologi Islam.
\end{abstract}

Kata Kunci: Psikologi Islam, Kejiwaan, Psikologi Barat

\section{A. Pendahuluan}

Psikologi Islam adalah sebuah kajian yang baru dikembangkan di awal tahun 60-an. Karenanya tak heran bila kemudian belum banyak yang mengenalnya; terlebih karena penarapannya belum begitu jelas. Ia masih suatu hal yang perlu dirumuskan kembali.

Kajian ini bermula dari usaha Dr. Zakiah Drajat yang mulai mengenalkan psikologi dari tinjauan agama. Namun baru pada tahun 1994, melalui simposium nasional, para peminat psikologi Islam akhirnya dikumpulkan dan muncullah kesepakatan untuk menamakan pengetahuan baru tersebut dengan nama psikologi Islam, setelah sebelumnya, banyak nama diusulkan, di antaranya adalah Psikologi Qur'ani, Psikologi Tasawuf dan lain sebagainya. 
Namun pada dasarnya, bisa dibilang, kajian psikologi Islam bukanlah satu kajian baru. Kajian ini sudah dibahas sejak lama, baik oleh para psikolog yang mendalami Islam ataupun oleh para dai atau ulama yang mencoba mendalami kajian psikologi ala barat. Dari persinggungan dua arah inilah akhirnya mereka bertemu pada satu kajian yang sama, yakni kajian psikologi Islam, kajian yang mencoba memahami eksistensi manusia dari sisi pandang ajaran Islam yang merujuk kepada al-Qur`an dan Sunnah.

Secara umum, manusia -sebagai objek kajian psikologi- adalah makhluk yang mampu berpikir dan merasa. Prilaku yang ditampakkannya adalah cerminan atas apa yang dipikir dan dirasakannya. Atas dasar inilah psikologi mencoba mengkaji lebih jauh akan gejala-gejala yan tampak dari apa yang dipikirkan dan dirasakan oleh manusia. Kajian gejala yang ada dalam diri manusia ini memiliki parameternya sendiri yang sistematis dan posivistik. Namun demikian, kenyataan membuktikan bahwasannya kajian ini tidak bebas bias, khususnya bias kultur. Itulah sebabnya mengapa kajian psikologi yang sukses di barat terkadang kurang bisa di aplikasikan pada setting yang berbeda darinya. Hal ini tentunya mengaplikasikan akan adanya keberagaman latar belakang (indigenous) yang kesemuanya memiliki karakteristik masing-masing.

Selain kultur yang memiliki orisinalitasnya tersendiri, Islam pun sebagai suatu ajaran agama dan juga keyakinan pun memiliki indegenous atau keoriginalannya sendiri. Sebagai ajaran, Islam adalah konsep yang berada di luar diri pemeluknya; namun sebagai keyakinan, Islam menjadi bagian dari pemeluknya. Untuk mendalami kejiwaan kaum muslim, dibutuhkan kajian tersendiri yang selama ini tidak tersentuh oleh kajian psikologi barat. Kajian inilah yang menjadi fokus kajian psikologi Islam. Kajian ini berproses dalam mencari formatnya yang pas dengan tujuan untuk dapat memahami kejiwaan kaum muslimin khususnya, dan juga manusia pada umumnya; baik yang bersifat materi maupun yang immateri. Kajian ini pun berusaha menguak gejala-gejala yang tampak pada kaum muslimin -khususnya gejala yang tidak dipahami keberadaannya dan eksistensinya oleh para psikolog barat, seperti gejala untuk mati syahid dll. Gejala yang tampak akan sangat beragam, sebagaimana keragaman pemahaman tiap individu muslim akan Islam itu sendiri. ${ }^{1}$

${ }^{1}$ Achmad Mubarak, Mengaji Islam dari Rasional hingga Spiritual, Jakarta: Binawera Pariwara, 2004 


\section{B. Pengertian Psikologi Islam}

Penamaan kajian psikologi yang mengulas permasalahan manusia dari perspektif Islam sebenarnya masih diperdebatkan; belum ada kesepakatan apakah Psikologi Islami (Islamic Psychologi) ataukah Psikologi Islam (Psychology of Islam).

Hanna Djumhana Bastaman, Djamaluddin Ancok, Fuad Nashari Suroso, Subandi, adalah nama-nama yang setuju menggunakan istilah Psikologi Islami (Islamic Psychologi). ${ }^{2}$ Sebagian besar cendikiawan dan psikolog muslim pun menggunakan istilah ini. Hanna Djumhana Bastaman berargumentasi bahwa dengan penggunaan istilah Psikologi Islami tergambarkan karakteristik dan identitasnya yang bersumber pada nilainilai Islami. Hanna pun memberikan rumusan psikologi Islam sebagai berikut,

'Psikologi Islami adalah corak psikologi berlandaskan citra manusia menurut ajaran Islam, yang mempelajari keunikan manusia dan pola perilaku manusia sebagai ungkapan pengalaman interaksi dengan diri sendiri, lingkungan sekitar, dan alam keruhanian, dengan tujuan meningkatkan kesehatan mental dan kualitas keberagamaan.'

Dari rumusan di atas bisa dipahami beberapa unsur, yakni pertama, corak psikologinya, artinya sebuah gerakan Islamisasi Psikologi, bahkan bisa menjadi mazhab psikologi mutakhir yang berlandaskan nilai-nilai ajaran Islam dengan tidak mengesampingkan metodologi dan metode ilmiah. Kedua, berdasarkan citra manusia menurut ajaran Islam, artinya berbeda dengan psikologi sekuler yang landasan filosofisnya bermacam-macam dan orientasi filosofisnya memberikan otoritas tertinggi kepada kehendak manusia. Ketiga, keunikan dan pola perilaku manusia. Perilaku manusia merupakan obyek telaah Psikologi secara luas. Perilaku manusia adalah ungkapan manifestasi dan ekspresi jiwa yang melibatkan fungsi-fungsi jiwa, yakni: perasaan, pikiran, sikap, pandangan dan keyakinan hidup. Keempat, interaksi dengan diri sendiri, lingkungan sekitar, dan alam keruhanian. Salah satu karakteristik manusia adalah adanya kesadaran untuk selalu introspeksi, berdialog dengan dirinya sendiri, dan selalu berhubungan dengan lingkungan alam fisik. Manusia dalam perspektif psikologi Islami memiliki ruh yang seharusnya memperluas lahan kajiannya dengan pengalaman keruhanian manusia. Kelima, meningkatkan kesehatan mental dan kualitas keberagamaan. Tujuan utama psikologi dan psikologi Islami adalah mental health. Kriteria sehat mental antara lain: terbebasnya individu dari gejala-gejala kejiwaan (neuroses) dan gejala-gejala penyakit psikhis (psychoses), mampu beradaptasi dalam pergaulan sosial, terjadinya harmonisasi diantara

\footnotetext{
${ }^{2}$ Lihat beragam tulisannya yang menggunakan Istilah Psikologi Islami seperti Psikologi Islami karya Jamaluddin Ancok \& Fuad Nashori dan Integrasi Psikologi dengan Islam, karya Hanna D. Bastaman
} 
fungsi-fungsi jiwa, yakni: pikiran, perasaan, sikap, pandangan dan keyakinan hidup, serta mampu mengoptimalkan dan merealisasikan potensi diri. Individu yang memenuhi kriteria sehat dalam perspektif Psikologi Islami menjadi salah satu tujuan, karena kondisi sehat mental merupakan hal yang kondusif bagi pening-katan kualitas religiusitas sebagai ungkapan iman dan taqwa kepada Tuhan. Inilah misi utama psikologi Islami, yaitu membantu mengembangkan individu dan masyarakat yang sehat mental sekaligus meningkatkan kualitas keimanan dan ketaqwaan.

Sedangkan penggunaan nama Psikologi Islam dipelopori oleh Abdul Mujib \& Jusuf Mudzakir. ${ }^{3}$

Nama lain yang juga pernah digunakan adalah psikologi Profetik. Istilah ini digagas oleh Yayah Khisbiyah (1998) dengan pengertian adalah sebuah kajian psikologi yang didasarkan pada kenabian Muhammad Saw. Nama ini ia gunakan atas ide Kuntowijoyo dalam Paradigma Islam: Interpretasi untuk Aksi (1991) terkait ilmu sosial profetik.

\section{Sejarah Munculnya psikologi Islam}

Kajian akan manusia berawal dari sejarah manusia itu sendiri. Beberapa referensi Alqur'an mengungkapkan relevansi psikologis dalam narasi al-Qur'an tentang kisah dua putera Adam, dimana salah seorang dari mereka (Qabil) melakukan pembunuhan atas saudaranya (Habil). ${ }^{4}$

"Maka hawa nafsu Qabil menjadikannya menganggap mudah membunuh saudaranya, sebab itu dibunuhnyalah, maka jadilah ia seorang diantara orang-orang yang merugi. Kemudian Allah menyuruh seekor burung gagak menggali-gali di bumi untuk memperlihatkan kepadanya (Qabil) bagaimana dia seharusnya menguburkan mayat saudaranya. Berkata Qabil: "Aduhai celaka aku, mengapa aku tidak mampu berbuat seperti burung gagak ini, lalu aku dapat menguburkan mayat saudaraku ini?" Karena itu jadilah dia seorang diantara orang-orang yang menyesal”.

Kisah diatas menjelaskan tentang motivasi psikologis yang menyimpang (kecemburuan yang berlebihan) dan pengaruhnya terhadap perilaku manusia. Satu pelajaran lainnya dalam episode ini ialah bahwa manusia pun bisa belajar melalui proses imitasi (Qabil meniru burung gagak yang menggali tanah untuk menguburkan jasad

\footnotetext{
${ }^{3}$ Lihat istilah yang digunakan dalam bukunya, Nuansa-Nuansa Psikologi Islam karya Abdul Mujib \& Yusuf Mudzakir. Menurutnya, psikologi Islam merupakan salah satu dari kajian keislaman. Penempatan kata Islam memiliki arti, corak, cara pandang, pola pikir, paradigma atau aliran psikologi yang dibangun bercorak ajaran Islam, sebagaimana yang berlaku dalam tradisi keilmuan Islam

${ }^{4}$ QS. Al Maidah: 30-31
} 
saudaranya). Proses peniruan ini dalam psikologi dikenal sebagai asas perilaku (behavioristik) dari teori modelling (percontohan) Albert Bandura.

Melalui ide-ide Alquran inilah, para ilmuwan Islam melakukan pengkajian tentang psikologi. Diantaranya dilakukan oleh Al-Kindi (185-260H/801-866M) yang dipandang sebagai filosof muslim pertama yang membahas tentang psikologi mengenai 'Tidur dan mimpi ${ }^{5}$. Dalam bukunya ia membahas berbagai fungsi jiwa, dan tentang cara kerja pikiran manusia. Dilanjutkan oleh Ibn Sina (370-428 H/980-1037 M) seorang filosof dan ahli kedokteran yang banyak memberikan sumbangsih dalam kajian Psikologi. Dalam bukunya, al-Syifa, Ibnu. Sina membahas tentang jiwa, eksistensinya, hubungan jasmaniruhani, sensasi, persepsi dan aspek-aspek terkait lainny; juga membedakan antara persepsi internal dan eksternal. Juga dijelaskan beberapa emosi manusia yang tidak dimiliki binatang, seperti heran, senyum, tangis dan sebagainya. Disamping itu, dia juga mencoba menerangkan beberapa penyakit somatik. Sedangkan Al-Ghazali (450-505 H/1043-111M) memainkan peranan penting dalam sejarah perkembangan semua cabang ilmu yang ada kaitannya dengan psikologi. Hal ini diperkuat oleh pernyataan Abdul Hamid al-Hasyimi, seorang Profesor psikologi di Universitas Raja Abdul Aziz bahwa orang pertama yang menamai cabang ilmu psikologi sebagai ilmu yang mengkaji jiwa dan behavior (perilaku) manusia adalah al-Ghazali ${ }^{6}$. Hal ini tampak dalam kitabnya 'Ihya 'Ulumuddin' yang membahas tentang jiwa dan perilaku manusia. Al-Ghazali membagi struktur keruhanian manusia ke dalam empat dimensi, yakni Kalbu, Ruh, Akal, dan Nafsu.Keempat unsur tersebut masing-masing memiliki dua arti, yakni arti jasmaniyah dan arti ruhaniyah ${ }^{7}$.

Pada beberapa dekade setelahnya, wacana islamisasi sains semakin meningkat, tak terkecuali bidang ilmu psikologi. Hal tersebut ditandai dengan simposium internasional Psikologi di Riyadh (1978). Simposium tersebut dilatar-belakangi oleh ditutupnya sebuah fakultas psikologi sebuah perguruan tinggi di Saudi Arabia dan kegiatan tersebut berupaya mengkritisi teori-teori psikologi yang dipandang cendekiawan muslim banyak menyesatkan umat Islam dan aqidahnya. Salah seorang yang tampil pada acara tersebut adalah Malik B. Badri. Ia menghadirkan pemikiran yang kritis atas aliran-aliran psikologi Barat, terutama psikoanalisa dan psikologi behavioristik. Pemikirannya yang sangat kritis

\footnotetext{
${ }^{5}$ Lihat tulisan Amber Haque yang berjudul Psychology from Islamic Perspective; contributions of Islamic Muslim Scholar and challenges to contemporary muslim psychologist yang dimuat di Journal of religion and health, Vol 43 no 4, Winter 2004

${ }^{6}$ M.G. Husain, Psychology and Society in Islamic Perspective, Pustaka, 1996, terj. Karsidi Diningrat, Psikologi dan Masyarakat dalam Perspektif Islam, hal. 16-17

${ }^{7}$ Imam al-Ghazali, Ihya "Ulumuddin, Dar al-Fiqr Bairut, juz. 4, hal. 4.
} 
mendapat perhatian dari banyak kalangan, hingga diterbitkanlah buku, The Dilemma of Muslim Psychologists (1979), sebuah buku yang banyak menggairahkan diskusi di kalangan mahasiswa, aktivis dan intelektual muslim.

Dalam bukunya, Malik B. Badri mengkritisi dunia Islam yang berada di bawah pengaruh budaya sekuler Barat; dimana banyak ilmuwan muslim sangat tergila-gila terhadap semua aspek peradaban yang datang dari Barat, termasuk teori-teori Psikologi Barat. Malik B. Badri mengungkapkan tiga fase perkembangan sikap psikolog muslim terhadap psikologi modern yang berasal dari Barat, yaitu: fase infantuasi, fase rekonsiliasi dan fase emansipasi.

Pada fase pertama, mereka sangat terpesona dengan teknik dan teori-teori psikologi modern. Mereka mengikuti sepenuh-nya teori dan metode psikologi sekuler tanpa kritik. Fase kedua, adalah fase penerimaan, mereka mencoba mengadakan studi komperatif, dan mencoba mencocokkan apa yang ada dalam teori psikologi Barat dengan apa yang ada dalam al-Qur'an. Mereka beranggapan di antara keduanya memiliki kesejalanan (paralelisasi) dan tidak ada pertentangan. Fase terakhir, mereka makin bersikap kritis terhadap pandangan-pandangan psikologi sekuler dan mengalihkan perhatian-nya pada alQur'an, al-Hadits dan khazanah klasik Islam yang di dalamnya ternyata membahas tentang struktur insan (nafs, qlb, aql, ruh). Menyadari akan kekeliruannya, mereka mulai kritis menentang beberapa teori dari psikologi sekuler, terutama pandangan teori psikoanalisa dan behaviorisme, karena kedua teori itu merendahlan martabat manusia sebagai hamba dan khalifah Allah, sedangkan pandangan humanistik yang mengakui potensi diri manusia dianggap sejalan dengan ajaran Islam. ${ }^{8}$

Setelah terbitnya tulisan Badri, di Timur Tengah terbit pula buku Nahw 'Ilm al-Nafs al-Islamy karya Hasan Muhammad Syarqawi (1979), 'Ilm al-Nafs al-Ma'ashir fi al-Islam (1983) karangan Muhammad Mahmud. Selain itu, bermunculan pula buku-buku serupa di Indonesia, seperti Nafsiologi (1986) yang ditulis oleh Sukanto M.M, , Asas-asas Psikologi Ilahiyah (1990) yang ditulis oleh Zuardin Azzaino dan juga Pengantar Psikologi alQur'an (1992) yang ditulis oleh Lukman Saksono dan Anharuddin.

Beriringin dengan Simposium Nasional Psikologi Islam I, momentum psikologi Islam di Indonesia pun makin tampak, khususnya dengan terbitnya sebuah buku hasil karya Djamaluddin Ancok \& Fuad Nasahari Suroso yang berjudul Psikologi Islami, Solusi Islam atas Problem-problem Psikologi (1994). Buku tersebut mengkritisi psikologi Barat

\footnotetext{
${ }^{8}$ Malik B. Badri, The Dilemma of Muslim Psychologists, terj. Siti Zainab Luxfiati, Pustaka Firdaus, 1996, cetakan ke-6, hal. 81-84.
} 
dengan lebih jauh menggali psikologi perspektif Islam tentang jiwa dan perilaku manusia. Momentum tersebut pun makin lengkap dengan terbitnya sebuah buku seorang ilmuan psikologi yang sampai saat ini menggeluti wacana Psikologi Islami - Hanna Djumhana Bastaman- berjudul Integrasi Psikologi dengan Islam Menuju Psikologi Islami pada tahun 1995. Buku tersebut adalah kumpulan berbagai makalah yang ditulisnya pada berbagai pertemuan ilmiah dan artikel yang pernah dipublikasikannya dengan tema Psikologi Islami dan di edit secara apik oleh seorang psikolog muda, editor buku Fuad Nashari Suroso.

\section{Ruang Lingkup Psikologi Islam}

Kajian Psikologi secara umum adalah mengkaji perilaku manusia. Namun secara khusus, kajian Psikologi Islam memiliki ciri khas yang tidak dimiliki aliran psikologi lainnya. Baharuddin mengungkapkan bahwa psikologi Islam adalah sebuah aliran baru dalam dunia psikologi yang mendasarkan seluruh bangunan teori-teori dan konsepkonsepnya kepada Islam. ${ }^{9}$

Ciri khas psikologi Islam dapat dipahami dalam tiga pengertian. Pertama, bahwa psikologi Islam merupakan salah satu dari kajian masalah-masalah keislaman. Ia memiliki kedudukan yang sama dengan disiplin ilmu keislaman yang lain, seperti Ekonomi Islam, Sosiologi Islam, Politik Islam, Kebudayaan Islam, dan sebagainya. Artinya, psikologi yang dibangun bercorak atau memiliki pola pikir sebagaimana yang berlaku pada tradisi keilmuan dalam Islam, sehingga dapat membentuk aliran tersendiri yang unik dan berbeda dengan psikologi kontemporer pada umumnya.

Kedua, bahwa Psikologi Islam membicarakan aspek-aspek dan perilaku kejiwaan manusia. Aspek-aspek kejiwaan dalam Islam berupa al-Ruh, al-Nafs, al-Kalb, al-` Aql, alDamir, al-Lubb, al-Fu'ad, al-Sirr, al-Fitrah, dan sebagainya. Masing-masing aspek tersebut memiliki eksistensi, dinamisme, proses, fungsi, dan perilaku yang perlu dikaji melalui alQur'an, al-Sunnah, serta dari khazanah pemikiran Islam. Psikologi Islam tidak hanya menekankan perilaku kejiwaan, melainkan juga apa hakekat jiwa sesungguhnya.

Ketiga, bahwa Psikologi Islam bukan netral etik, melainkan sarat akan nilai etik. Dikatakan demikian sebab Psikologi Islam memiliki tujuan yang hakiki, yaitu merangsang kesadaran diri agar mampu membentuk kualitas diri yang lebih sempurna untuk mendapatkan kebahagiaan hidup di dunia dan akhirat. Manusia dilahirkan dalam kondisi tidak mengetahui apa-apa, lalu ia tumbuh dan berkembang untuk mencapai kualitas hidup.

\footnotetext{
${ }^{9}$ Baharuddin, Aktualisasi Psikologi Islam, (Yogyakarta: Pustaka Pelajar, 2005).
} 
Dengan kekhasan di atas, Psikologi Islam sudah sepatutnya menjadi wacana sains yang objektif, bahkan boleh dikatakan telah mencapai derajat supra ilmiah, karena ruang lingkupnya menjadi lebih luas dari kajian psikologi lainnya.

Namun demikian, Psikologi Islam tetap mengarah pada pendekatan kajian sains dan kajian ilmu agama; yang secara spesifiknya adalah mendekatkan kajian psikologi pada umumnya dengan kajian al-Qur`an. Dengan demikian maka dipahami bahwa landasan filsafat ilmu dari psikologi Islam adalah konsep manusia menurut al-Qur`an. Mujib mengemukakan bahwa dalam konsep manusia menurut al-Qur`an adalah konsep yang menyatakan bahwa manusia bukan hanya terstruktur dari jasmani; tapi juga ruhani. Sinergi keduanya inilah yang membentuk nafsani. Dari ketiga sistem inilah terbentuk kepribadian individu manusia.

Pendekatan yang ada, dilandasi dengan sumber wawasan dan landasan psikologi Islam yakni Al-Qur'an. Pendekatan psikologi dalam hal ini dapat digunakan untuk membuka rahasia sunnatullah yang bekerja pada diri manusia (ayat nafsani), dalam pengertian menemukan berbagai asas, unsur, proses, fungsi dan humum-hukum mengenai kejiwaan manusia. ${ }^{10}$

Dikala Psikologi tradisional (sekuler) berasumsi bahwa alam semesta secara keseluruhan bersifat materi, tanpa makna dan tujuan; dan manusia tidak lebih dari organisme tubuh, pikiran manusia berkembang berasal dari sistem syaraf tubuh semata dan tidak mengakui adanya dimensi spiritual, kajian psikologi Islam memiliki pandangan yang berbeda. Kajian Psikologi Islam mencoba memahami manusia dalam kerangka Islam.

Beberapa paradigma khas psikologi Islam terkait manusia adalah sebagai berikut:

Pertama, mempercayai bahwa hakikat manusia adalah fitrah, baik secara jasadi, nafsani (kognitif dan afektif), maupun ruhani (spiritual). Tentang fitrah secara spiritual, Ibn Taimiyah mengungkapkan bahwa fitrah manusia adalah memiliki pengetahuan tentang Allah, mencintai Allah dan memiliki komitmen untuk melaksanakan agama Allah. Hal ini merujuk kepada firman Allah, "Maka hadapkanlah wajahnya dengan lurus kepada agama Allah); (tetaplah atas) fitrah Allah yang telah menciptakan manusia menurut fitrah itu. Tidak ada perubahan pada fitrah Allah. (itulah) agama yang lurus; tetapi kebanyakan manusia tidak mengetahui $", 11$.

\footnotetext{
${ }^{10}$ Hannna Djumhana Bastaman, Integrasi Psikologi dengan Islam Menuju Psikologi Islami, Pustaka Pelajar, Jogyakarta, 1997, cet.ke-2, hal. 4.

${ }^{11}$ QS. Ar Ruum: 30
} 
Juga merujuk kepada ungkapan Muhammad saw, "Seseorang tidak dilahirkan kecuali dalam keadaan fitrah, maka kedua orang tuanyalah yang menjadikannya Yahudi, Nasrani, dan Majusi”.

Manusia memiliki cinta, ingin menyenangkan diri sendiri dan orang lain, memiliki kemampuan mengetahui, memahami, menciptakan. Psikologi Huma-nistik mengakui secara alamiah manusia memiliki potensi baik, namun tidak pernah mengakui adanya pengetahuan-cinta-komitmen kepada Allah.

Kedua, mempercayai bahwa salah satu komponen terpenting manusia adalah qalb (hati nurani). Sesungguhnya perilaku manusia tergantung kepada qalbunya yang secara fisik disebut mudghah.. Hal ini merujuk kepada suatu hadis, "...ingatlah bahwa sesungguhnya dalam jasad manusia terdapat mudghah. Jika mudghah itu baik, maka baiklah seluruh tubuh. Jika mudghah itu rusak, maka rusaklah seluruh tubuh. Mudghah itu adalah qalbu”

Di samping jasad, akal, manusia memiliki qalbu. Dengannya manusia dapat mengetahui sesuatu (di luar nalar), kecenderungannya kepada yang benar dan bukan yang salah (termasuk memiliki kebijaksanaan, kesabaran) dan memiliki kekuatan yang mempengaruhi benda dan peristiwa. Nabi-nabi dan Rasul-rasul adalah contoh pribadipribadi yang qalbunya berkembang optimal, sehingga mereka dapat mengetahui sesuatu yang tidak tampak dengan cara yang tidak biasa (melalui wahyu/ilham), tidak pernah goyah berpegang pada nilai kebenaran, dan memiliki berbagai kemampuan mempengaruhi sesuatu (seperti psychokinetik, out of body experience).

Pandangan psikologi Islami tentang kalbu berbeda dengan psikologi Barat yang dalam menjelaskan sesuatu selalu menggunakan pendekatan rasional (otak). Otak manusia menurut psikologi Barat adalah pusat kecerdasan intelektual, kecerdasan emosional dan kecerdasan spiritual. Padahal sebenarnya manusia memiliki unsur-unsur psiko-spiritual meliputi al- 'aql, al-qalb, dan al-nafs. Unsur pembentukannya (elemen asalnya) adalah aljism dan al-ruh.

Ketiga, mempercayai bahwa arah pergerakan hidup manusia secara garis besar dibagi menjadi dua. Allah Swt telah mengisyaratkan adanya dua jalan bagi manusia, yaitu jalan taqwa dan jalan fujur. Rujukannya adalah bahwa manusia diciptakan dalam keadaan fitrah dan ia bergerak ke arah taqwa. Bila manusia berjalan lurus antara fitrah dan Allah, maka ia akan menjadi taqwa (sehat, selamat). Sebaliknya, jika tidak lurus antara fitrah dan Allah maka ia akan berjalan ke pilihan yang sesat (fujur). Secara fitrah, manusia diciptakan 
dengan penuh cinta, memiliki cinta, namun ia dapat berkembang ke arah agresi (alghadhab). Tugas psikologi Islami adalah agar manusia selalu lurus dengan fitrahnya.

Keempat, mempercayai bahwa manusia adalah unik. Quraish Shihab menyebutkan khalqan akhir. Keunikan manusia bukan hanya secara jasadi, nafsani, tapi juga ruhani. Misalkan seseorang yang karena dido'akan oleh ayah atau kakeknya yang 'alim secara ruhaniah lebih kuat, lebih mudah mencapai keberhasilan dibandingkan dengan yang tidak dido'akan.

Kelima, psikologi Islami dibangun berdasarkan nilai tertentu, bukan netral etik. Kita percaya bahwa setiap aliran pasti dipengaruhi nilai tertentu. Psikoanalisis Freud banyak menggunakan pemikiran Darwin (misalnya manusia tidak lebih dari binatang). Behaviorisme Watson menggunakan rujukan filsafat empirisme (misalnya manusia semata-mata dipengaruhi oleh lingkungannya). Psikologi islami berangkat dari nilainilai Islam. Gagasan tentang ilmu yang netral etik, sebagaimana diungkapkan Gunnar Myrdal adalah khayalan belaka. Setiap ilmu berangkat dari nilai-nilai-nilai dan mengembangkan nilai-nilai.

Walaupun sumber utama kajian psikologi Islam adalah al-Qur'an, namun kajian ini pun memandang bahwa teori yang berasal dari Barat dan bersesuaian dapat direkonstruksi ke dalam paradigma psikologi Islam. Pandangan Dollard dan Miller tentang frustrationagression hypothesis yang mengungkapkan bahwa frustrasi akan menimbulkan rasa marah dan rasa marah akan memunculkan agresivitas adalah pandangan yang dapat diterima oleh psikologi Islami. Cerita al-Qur'an tentang frustrasi Qabil yang gagal menyunting Iqlima yang cantik dan berakhir pembunuhan atas diri Habil adalah contoh dari kesesuaian teori Dollard dan Miller tersebut.

Namun dikala teori yang ada bersebrangan, maka teori tersebut tidak bisa direkonstruksi ke dalam paradigma psikologi Islam. Pernyataan bahwa setiap frustrasi/kemarahan akan menghasilkan agresi adalah pernyataan yang sangat bersebrangan dengan kajian psikologi Islam. Kajian ini memiliki teori yang disebut al-Basith (kelapang dadaan), yaitu sebuah ruang yang luas dalam qalbu manusia yang memungkinkannya menerima realitas apapun, termasuk yang pahit sekalipun. Nurani tetap menyerahkan diri kepada Allah. Salah satu firman Allah berkaitan dengan kelapang dadaan:

"Bukanlah Kami telah meluaskan dadamu untukmu”.

Contoh nyatanya tampak pada Ali bin Abi Thalib yang tidak mau menggoreskan pedang di leher seorang kafir, karena ia tidak mau pembunuhan terjadi karena hawa nafsunya. Sedemian lapangnya hati nurani seseorang hingga ia tidak pernah sakit hati saat 
didzalimi oleh orang banyak sekalipun. Dengan kelapangdadaan pula Nabi Muhammad Saw. berdo'a terhadap penduduk Thaif yang melempari dengan batu dan mengusirnya. Dengan basith di hatinya, nabi Muhammad Saw pun menerima realitas seperti itu, saat diludahi orang Yahudi; bahkan ketika orang itu tidak pernah meludahinya kembali, nabi menanyakan dan mengunjunginya. Sikap seperti ini (al-akhlaq al-mahmudah) yang diperlihatkan oleh Nabi memperoleh simpati yang luar biasa.

Beberapa pandangan psikologi Barat yang kontradiktif dengan pandangan Islam tentu saja tidak bisa diterima. Diantaranya adalah anggapan Freud bahwa shalat adalah perilaku obsessif kompulsif, bahwa beragama sebagai ilusi, keyakinan akan Tuhan sebagai pengalihan Oedipus Complex ataupun bahwa kebaikan dan kebenaran (biasa disebut dalam konsep Freud sebagai superego) hanya berasal dari diri manusia dan tidak inheren dalam diri manusia.

Hal tersebut mengacu pada formulasi pemikiran ulama besar Syekh Taqiyyuddin An Nabhany dalam kitabnya Nidlomul Islam yang mengemukakan bahwa untuk menfilter diterima atau ditolaknya suatu pemikiran dan peradaban kontemporer maka digunakan konsepsi Hadlarah wal Madaniyah. Hadlarah (produk pemikiran) dan madaniyah (produk benda) yang datang dari arah manapun selama tidak bertentangan dengan aqidah dan syariah Islam maka boleh diambil; Sementara jika bertentangan dengan Islam walaupun sekecil biji sawi (mitsqala dzarrah), tentu tidak diambilnya.

Secara tegas, yang membedakan antara psikologi sekuler dengan psikologi Islami adalah dari orientasi filosofisnya. Psikologi Barat memandang manusia sebagai pusat segala kehendak, pusat segala relasi (antrophosentris), sedangkan psikologi Islami memandang manusia di samping diberikan kebebasan untuk berusaha dan berikhtiar, dan berrelasi, tetapi Tuhanlah sebagai pusat relasi dan semua keputusan vonis berada di atas iradah-Nya (antropho-theosentris). Dalam rumusan konsep manusia dan cara mendekatinyapun berbeda, psikologi Barat semata-mata hanya menggunakan kemampuan intelektual untuk menemukan dan mengungkap asas-asas kejiwaan, sementara psikologi Islami mendekatinya dengan memfungsikan akal dan keimanan.

\section{E. Prospek Kajian Psikologi Islam}

Upaya pengembangan psikologi yang bermuatan nilai-nilai ke-Islaman didasarkan pada beberapa asumsi: pertama, para ahli mensinyalir bahwa abad ini adalah zamannya kecemasan (anxiety) dan kegelisahan (restlessness). Dunia mengalami krisis moral dan kepercayaan, sehingga kondisi kejiwaan seseorang mulai membutuhkan suasana yang 
menyejukkan. Salah satu solusi yang dipandang cukup signifikan dalam menyelesaikan problem kejiwaan tersebut adalah dengan menghadirkan diskursus psikologi. Kedua, psikologi kontemporer sekuler yang hanya semata-mata menggunakan kemampuan intelektual belum mampu memecahkan problem kejiwaan manusia, dan memang sesuai dengan cirinya yang netral-etik-antrophosentris, psikologi ini memaksakan diri hanya pada pendekatan empiris. Akibatnya, psikologi tercerabut dari akar pengertiannya yang semula bermaksud membahas tentang jiwa manusia dialihkan pada pembahasan "gejala jiwa". Perubahan ini memunculkan kritik terhadap keberadaan psikologi, yang didefinisikan sebagai "ilmu jiwa yang tidak mempelajari jiwa, atau ilmu jiwa yang mempelajari manusia tidak berjiwa".

Untuk mengatasi fenomena ilmu jiwa tanpa jiwa itulah kajian ini seolah memiliki keunikannya sendiri yang terfokus pada bagaimana kajian ini menerangkan berbagai problem yang dihadapi oleh kaum muslimin dalam kehidupannya; bagaimana telaah kritis terhadap konsep-konsep dan teroi-teori psikologi yang dipandang menyimpang dari ajaran Islam serta bagaimana tawaran konsep alternatif tentang psikologi, yakni dengan membangun konsep islamisasi psikologi.

Kajian Psikologi Islam akan semakin efektif bila dianalisis secara optimal; meminjam tipologi Jamaluddin Ancok, setidaknya pengembangan Psikologi Islami dapat dibagi menjadi tiga cara. Pertama, psikologi dipakai sebagai pisau analisis masalahmasalah psikologis umat Islam. Kedua, Islam dijadikan "pisau analisis bagi pengkajian psikologi. Ketiga, membangun konsep psikologi baru yang didasarkan pada nilai-nlai Islam. $^{12}$

Semua cara yang ada tentunya mengurangi kekurangan dan kelebihannya masingmasing. Pemanfaatan psikologi untuk memberikan penjelasan problem umat Islam serta mening-katkan sumber daya umat Islam adalah satu kelebihan; namun demikian, hal tersebut terbatas pada konsep-konsep psikologi tertentu dengan kemungkinan bias yang sangat besar, karena seringkali mereduksi Islam ke dalam pengertian yang parsial dan tidak utuh.Cara ini tampak dari karya tulis Zakiah Daradjat yang berjudul Pokok-pokok Kesehatan Mental dan Ilmu Jiwa

Sedangkan melakukan studi kritis terhadap psikologi untuk mengetahui kelebihan dan kelemahan konsep psikologi bisa direalisasikan dan menjadi satu kelebihan; namun cara ini terkadang membuat seseorang terjebak dalam memandang persoalan lebih

\footnotetext{
${ }^{12}$ Djamaluddin Ancok, Fuat Nahari Suroso, Psikologi Islami Solusi Islam atas Problem-problem Psikologi, Pustaka Pelajar, Yogjakarta, cet. Ke-6, 2005, hal. 3-4.
} 
dominan dari sudut pandang konsep psikologinya daripada Islamnya. Cara ini tampak dari karya tulis Zakiah Daradjat yang berjudul Ilmu Jiwa Agama; Kesehatan Menal; Perawatan Jiwa untuk Anak-anak, dan Pendidikan Agama dan Kesehatan Mental

Selain itu, membangun konsep psikologi baru yang didasarkan pada wawasan Islam melalui analisis kandungan al-Quran memungkinkan kita untuk membangun konsep Psikologi yang berwawasan Islam, melalui al-Qur'an, Sunnah Nabi, dan khazanah pemikiran Islam klasik. Cara ini tampak dari karya tulis Zakiah Daradjat yang berjudul Shalat Menjadikan hidup Bermakna (1988); Kebahagiaan; Haji yang Unik; Puasa meningkatkan Kesehatan Mental (1989); Doa Menunjang Semangat Hidup (1990); Zakat Pembersih Harta dan Jiwa (1991).

Selain Zakiah Daradjat dengan semua upayanya menemukan formulasi dan paradigma yang sesuai dalam memahami psikologi Islam, beberapa ilmuwan pun melakukan banyak hal serupa. Diantaranya Djamaluddin Ancok dan Fuat Nashari Suroso dalam karyanya Psikologi Islami, Solusi Islam atas Problem-problem Psikologi, dan Hanna Djumhana Bastaman dalam karyanya Integrasi Psikologi dengan Islam, Menuju Psikologi Islami. Ketiga karya tersebut mencoba memberi wawasan baru dalam diskursus Psikologi Islam kontemporer di Indonesia; walau bisa jadi mereka terjebak dalam frame sekuler yang menyalahi kode etik ilmiah qur'ani, bahkan dapat terperosok dalam "liang biawak" meminjam istilah Malik B. Badri, seperti menyamakan konsep al-ruh dengan spiritual.

Selain itu, Sukanto Mulyomartono dengan karyanya Nafsiologi; Suatu Pendekatan Alternatif atas Psikologi (1986) yang kemudian disempurnakan oleh A. Dardari Hasyim dengan judul Nafsiologi: Refleksi Analisis tentang Diri dan Tingkah Laku Manusia (1995) mencoba mengelaborasi substansi ajaran Islam ke dalam wacana psikologi, sehingga tercipta psikologi baru yang berlabel Islam. Dengan label baru itulah tampak garis pemisah yang jelas antara psikologi Islam dengan psikologi kontemporer Barat dimana melalui kajian Psikologi Islam, manusia mampu mengenal Tuhan, Agama, dan alam transenden; sebaliknya kajian psikologi Barat belum menjangkau wilayah ruh tersebut.

Dalam pandangan Fuad Anshari - sebagaimana termuat dalam bukunya Psikologi Islami: Agenda menuju Aksi (1997)- pengembangan psikologi Islam oleh para psikolog dan cendekiawan muslim dilalui dalam lima tahap, yakni fase terpesona, fase kritik, fase perumusan, fase penelitian dan fase penerapan. Fase terpesona ditandai oleh kekaguman terhadap teori-teori psikologi Barat, yang karena demikian takjubnya, hingga memunculkan psikologisme (apa-apa yang dianalisis secara psikologis). Fase kritik, 
ditandai oleh semangat meneliti, menelaah secara objektif, tajam dan kritis atas teori-teori psikologi Barat dan tentunya penolakan atas teori-teori psikologi Barat. Kedua fase ini dianggap sebagai persiapan pembentukan psikologi Islami atau fase-fase pra-psikologi Islami.

Fase berikutnya adalah perumusan teori. Berangkat dari pemahaman al-Qur'an dan al-Hadits serta penafsiran atas keduanya, dilengkapi dengan ayat-ayat nafsani (apa yang kita lihat dalam diri manusia), maka dapat dirumuskan teori psikologi Islami. Agar kokoh, kuat, maka teori harus ditopang oleh riset, sehingga teori itu konsisten dengan data, maka fase selanjutnya adalah melakukan penerapan. Bagian ini akan menjelaskan apa yang dapat kita lakukan untuk meriset psikologi Islami. Setelah hasilnya dirasakan stabil, maka penerapan adalah sesuatu yang bisa dilakukan.

Berangkat dari asumsi dan juga kemungkinan pengembangannya, maka bukan tidak mungkin riset akan kajian psikologi Islam menjadi satu kajian yang sangat memberikan prospek yang sangat cerah. Selain memberikan pemahaman yang sangat orisinal akan hakikat manusia itu sendiri, juga memberikan energi baru bagi para cendekiawan dan juga pemerhati untuk lebih memahami eksistensi manusia yang sesungguhnya.

Selain itu, bisa dikatakan bahwa prospek kajian ini ke depan bisa dikatakan sangat cerah; khususnya karena prinsip universalitas yang ada pada psikologi Islam yang membuatnya tidak hanya bisa diaplikasikan oleh kaum muslim belaka; namun juga bisa diaplikasikan oleh kalangan non-muslim. Sebuah lembaga Bantuan Psikologi Islam mengemukakan bahwa yang dinamakan Psikologi Islam adalah suatu ilmu tentang perilaku manusia yang berbasis aqidah dan syariah Islam; yang berbasiskan sumber ajaran Islam, Al-Qur'an, Sunnah, Ijma dan Qiyas; serta bisa diaplikasikan untuk mendeskripsikan, menganalisis dan menjawab problematika perilaku aktual, baik dalam lingkup Psikologi Organisasi \& Industri, SDM, Pendidikan, Sosial, Perkembangan, Klinis, Politik, dan sebagainya.

\section{F. Daftar Pustaka}

Abdul Hayyie al Kattani, Rekayasa Masa Depan Islam: Dengan Revitalisasi Warisan Klasik Islam (Turats) Sebagai Illustrasi, http://www.kmnu.org/.

Al-Ghazali, Ihyâ 'Ulûmu Al-Dîn. Bairut-libnan: Dâr al-Fikr, 1415 H/1995M.

Ancok, Jamaluddin Ancok \& Fuad Nashori, Psikologi Islami, Yogyakarta: Pustaka Pelajar, 2005. 
Asyarie, Sukmadjaya \& Rosy Yusuf, Indeks Al-Wur'an, Bandung: Pustaka, 1984.

Badri, Malik B, The Dilemma of Muslim Psychologists, terj. Siti Zainab Luxfiati, Pustaka Firdaus, 1996, cet ke-6

Baharuddin, Aktualisasi Psikologi Islam, Yogyakarta: Pustaka Pelajar, 2005. Paradigma Psikologi Islami, Yogyakarta: Pustaka Pelajar, 2007.

Bastaman, Hanna D. Bastaman, Integrasi Psikologi dengan Islam, Yogyakarta: Pustaka Pelajar, 2005

Chaplin, P. J., Kamus, Dictionary of Psychology, Penterj. Kartini Kartono , Jakarta: Rajawali Pers, 2000 cet. Ke-6,

Daradjat, Zakiah, Islam dan Kesehatan Mental, Jakarta: Gunung Agung, 1995.

---------------------, Kesehatan Mental, Jakarta: Gunung Agung, 1995.

-------------------, Ilmu Jiwa Agama, Jakarta: Bulan Bintang, 1970.

Frager, Robert. Heart, Self \& Soul. The Sufi Psychology of Growth Balance \& Harmony. Wheaton: The Theosophical Publishing House, 1999.

, Psikologi Sufi untuk Transformasi Hati, Diri, \& Jiwa. Alih Bahasa Hasmiyah Rauf, Jakarta: Serambi, 2002.

Haque, Amber. Psychology from Islamic Perspective; contributions of Islamic Muslim Scholar and challenges to contemporary muslim psychologist. Journal of religion and health, Vol 43 no 4, Winter 2004

Karsidi Diningrat, Psikologi dan Masyarakat dalam perspektif Islam, Bandung: Pustaka, 1996.

Mujib, Abdul \& Yusuf Mudzakir, Nuansa-nuansa Psikologi Islam, 2001.

Fitrah \& Kepribadian: Sebuah Pendekatan Psikologis, Jakarta: Darul Falah Jakarta, 1999.

Mubarak, Ahmad. Mengaji Islam dari Rasional hingga Spiritual. Jakarta: Binawera Pariwara, 2004

Najati, Muhammad Utsman, Psikologi Dalam Perspektif Hadits. (Alih Bahasa Zaenuddin Abu bakar dkk), Jakarta: Pustaka, 2004

Nashori, Fuad. Agenda Psikologi Islam, Yogyakarta: Pustaka Pelajar, 2000 